Article

\title{
Composting as Manure Disposal Strategy in Small/Medium-Size Livestock Farms: Some Demonstrations with Operative Indications
}

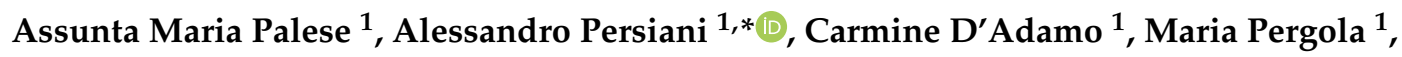 \\ Vittoria Pastore ${ }^{1}$, Rocco Sileo ${ }^{2}$, Giuseppe Ippolito ${ }^{2}$, Maria Assunta Lombardi ${ }^{2}$ and \\ Giuseppe Celano ${ }^{3}$ (D) \\ 1 Ages s.r.l. s—Spin-off Accademico, Università degli Studi della Basilicata, Viale dell'Ateneo, Lucano 10, \\ 85100 Potenza, Italy; palesedina@gmail.com (A.M.P.); carminedadamo@hotmail.it (C.D.); \\ mariateresa_pergola@virgilio.it (M.P.); ingvittoriapastore@gmail.com (V.P.) \\ 2 Agenzia Lucana di Sviluppo e di Innovazione in Agricoltura (ALSIA), Via Annunziatella 64, 75100 Matera, \\ Italy; rocco.sileo@alsia.it (R.S.); giuseppe.ippolito@alsia.it (G.I.); maria.lombardi@alsia.it (M.A.L.) \\ 3 Degree Course of Agriculture, Dipartimento di Farmacia (DIFARMA), Università degli Studi di Salerno, Via \\ Giovanni Paolo II 132, 84084 Fisciano (SA), Italy; gcelano@unisa.it \\ * Correspondence: persianialessandro@gmail.com
}

Received: 18 March 2020; Accepted: 16 April 2020; Published: 19 April 2020

\begin{abstract}
The livestock sector plays a fundamental role in human beings' livelihood all over the world. However, significant changes have occurred in the last decades, transforming the livestock sector into a highly intensive economic activity with negative impacts on human health and the environment. Such a reality requires the identification of easy methods to apply to sustainable manure management. Composting is a clever approach to transform manure into a resource. Very limited scientific literature is available on techniques for composting in small and medium livestock farms. This paper describes, in detail, some on-farm composting plants made in Southern Italy within different rural contexts. A depth analysis of farm starting situation and nearby territory (resources/services) was performed to identify the least expensive/impactful composting logistics (reduction of ex novo farm investments and transport costs, etc.), making the action economically sustainable for farmers. This approach appears to be successful in guiding farmers towards the best composting technological option, based on pre-existent on-farm resources. These small-scale composting plants, reproducible in other similar contexts, allow one to turn manure into a product with a profitable placement on the market. For this reason, these manure management options should be widespread, especially under organic farming systems.
\end{abstract}

Keywords: livestock farms; manure; demonstration tests; environmental impact; compost on-farm

\section{Introduction}

The agricultural sector, including animal husbandry, has undergone significant changes over the centuries. Particularly, a passage from an extensive farm management to an intensification of agricultural practices and land use has occurred as a result of the modernization process and the increasing demand for human foodstuffs at world level [1-3]. The livestock sector plays a major role in the economy of European Union (EU) countries where, in 2016, on average, more than half agricultural farms held livestock (54.8\%), though with the due differences [4]. In fact, taking into account the single Member State, Ireland showed the highest number of livestock farms (92\%) while Italy showed the lowest number (13.5\%). On the other hand, in recent years, EU farms with livestock have shown a substantial contraction; particularly, they have been down by more than one-third in the majority of 
the Member States (2005-2016 period) [4]. Differently, no significant variation was observed in the total EU livestock population, which remained stable-from 2013 to 2016-accounting for 131 million livestock units. The different livestock species also remained approximately the same, being made up of cattle at $49.0 \%$, of pigs at $25.2 \%$, and of $15.8 \%$ for poultry (reference year: 2016) [4]. As found at the European level, in Italy, a significant contraction in the number of zootechnical farms (those having the most relevant livestock species from an economic point of view: Cattle, buffaloes, and pigs) was observed from 1982 to 2010 (from 854,137 to 217,449) [5]. With respect to the livestock species, in the same period (1982-2010), an important decrease was recorded in cattle number while an increasing trend was observed for pigs and buffaloes [5]. At the same time, the yearly manure production of EU (at 27 member countries) is estimated at 1.4 billion tons [6]. A detailed breakdown of manure between livestock (pigs, cattle, and chickens) and manure types (solid, liquid, slurry), for each Member State, is reported in Foged et al. [6].

The current situation evidently corresponds to an increase of the negative pressure on the environment with livestock waste disposal being a very impactful item. As a matter of fact, manure spreading can have detrimental effect on air (emissions of greenhouse gases- $\mathrm{CO}_{2}, \mathrm{~N}_{2} \mathrm{O}$, and $\mathrm{CH}_{4}$, which contribute to climate change—and ammonia and particulate matter-which worsen air quality; unpleasant odor; noise from machinery and animals), water (eutrophication, acidification, worsening of drinking water quality, water pollution by xenobiotic compounds as emerging pollutants), soil (increase of heavy metals concentration), biodiversity (altered grasses composition disturbing, for instance, bird nests construction), and ecosystem services (loss of drinking water and bathing areas due to eutrophication) [7-9]. Therefore, the considerable manure amount produced within the EU must be managed properly considering the high environmental risk linked to its irrational disposal.

The Nitrates Directive (91/676/EEC) [10], then implemented by the individual EU Member State, was created with the aim of reducing and/or preventing water pollution caused by nitrates of agricultural origin (fertilizers and livestock effluents). This is of relevant concern for farmers who have to assure-especially in nitrate vulnerable zones-the correct livestock load. This last is considered as the quantities of produced nitrogen with respect to the agricultural area subjected to waste distribution. Therefore, the livestock nitrogen load should be calculated according to the utilized agricultural area (UAA). On the other hand, farms have smaller and smaller surfaces to be used for distribution compared to the nitrogen amounts contained in livestock effluents. In this case, it may be useful to reduce the volumes and/or the nitrogen load of the animal waste by adopting different treatment techniques within the farm.

Surely, the Nitrates Directive has represented the main driving force for adopting manure processing strategies. Manure treatment technologies can be classified on the basis of their objective (energy production, phase separation, nutrients recovery, nitrogen removal, etc.). Currently, 45 processing techniques have been identified as standalone technologies or belonging to combined treatment systems; each of them should be chosen taking into account local constraints and problems, and different economic, territorial, environmental, and political scenery [11]. Among the numerous manure processing technologies, composting can be an adequate proposal to optimize management of solid livestock manure or fiber fractions of slurries (solid manure of cattle and pig; cattle, pig, and poultry deep litter). Even the liquid manure fraction can be composted provided that enough bulking agent-pruning residues, wood chips, straw, all having structuring function-are added in order to absorb water, so as to obtain a solid mix with an adequate Carbon to Nitrogen ratio $(\mathrm{C} / \mathrm{N})$. Indeed, composting is a naturally occurring process and it can be accelerated by opportune operations. In detail, composting is a controlled aerobic biological decomposition of organic matter aimed to obtain a stable product to be used in agriculture—named compost—characterized by low moisture content, high levels of nutrients, without weed seeds and pathogens; furthermore, such technique reduces manure volumes, facilitating its storage and transport, and manure nitrogen content [12,13]. In detail, composted manure often contains less than half the nitrogen of fresh manure. In addition, composting converts the nitrogen contained in manure into a more stable organic form less susceptible 
to leaching and further ammonia losses, therefore being less impactful on the environment. Obviously, to preserve the environment, compost distribution has to be carefully managed taking into account the slow release of compost organic nitrogen, crop nutrient needs, and the used agronomic practices (such as fertilization systems, presence or absence of irrigation, soil management) [14]. Composting, by producing stabilized organic matter, feeds virtuous cycles of recovery of degraded soils, restores their fertility, and contributes to the sequestration of carbon in the soil; in addition, by reducing the inputs of fertilizers, pesticides, and fuels, it lowers production costs and reduces negative impacts of agricultural operations. Again, the compost supply chain (from the acquisition of the starting matrices to the distribution in the field) could involve various agricultural sectors, helping to solve some other critical issues, including the disposal of green waste (from forestry sector and urban green areas) and agro-industrial residues [15].

With respect to GHG's emissions produced during composting, $\mathrm{CO}_{2}$ is not considered as a gas contributing to global warming due to its biogenic origin [16]. The other $\mathrm{GHG}^{\prime} \mathrm{s}\left(\mathrm{N}_{2} \mathrm{O}\right.$ and $\left.\mathrm{CH}_{4}\right)$, though emitted in small quantities, contribute significantly to global warming, having warming potentials 25 $\left(\mathrm{CH}_{4}\right)$ and $296\left(\mathrm{~N}_{2} \mathrm{O}\right)$ times higher than that of $\mathrm{CO}_{2}$. A detailed list of papers reporting emissions of these gases, distinguished according to the type of the starting manure and the composting technology, is available in Sánchez et al. [17]. On the other hand, the uncontrolled disposal of animal wastes-as well as causing environmental impacts-do not allow their conversion into resource through the recovering of the organic matter and nutrients contained in them. In addition, there is a significant margin to reduce GHG emissions along the different composting stages transforming or adjourning the current facilities and by ameliorating the treatment techniques efficiency [17]. Regarding this, further scientific efforts should be performed to enrich the already available casuistry.

Composting procedure shows a low to medium level of complexity and it is applicable at different scale (on-farm, and at medium and large scale). Detailed information on actual manure processing activities in the EU (amount of manure processed per Member State, manure type, and the scale of operations) is reported in Foged et al. [6]. Among the solid livestock manure treatments, composting is the most widespread process showing 1180 farm size installations, 101 small-medium size installations (treating $<50,000$ tons year $^{-1}$ ) and 7 large-scale installations (treating $>50,000$ tons year $^{-1}$ ) treating, on average, 2730, 15,776, and 63,867 tons year $^{-1}$, respectively [6]. Greece and United Kingdom host the largest number of farm size installations (more than 400), while in Spain, there is the highest number of small-medium size and large-scale installations (83 and 43, respectively). On the other hand, according to Misra et al. [18], small-scale composting systems usually involve infrastructure and techniques easily applicable by farmers, from both technical and financial point of views, and are fine-tuned to suit specific circumstances. The amount of livestock manure and other products treated by means of composting is about $0.4 \%$ of the entire livestock manure production in the EU 27 [6].

The main objective of this article is promoting the composting techniques on farm, with the awareness that a wide diffusion of such strategies has to be recommended to optimize manure disposal while saving the environment. Obviously, the transfer of this manure management approach cannot be separated from the stakeholders' knowledge of the compost and its benefits. For this purpose, a series of on-farm composting experiences are reported in order to provide satisfactory solutions/alternatives to the different socio-economic and territorial conditions of some areas within Basilicata, a small region of Southern Italy. Particularly, the suggested composting solutions were chosen with the specific aim of containing costs so as to make the action economically sustainable for the farmer. Therefore, the operative proposals were calibrated according to the facilities within the farms-that voluntarily joined the transfer and disclosure action-to limit ex novo investments as much as possible. 


\section{Materials and Methods}

\subsection{The Study Context}

Basilicata shows a high agricultural aptitude producing several typical and excellent quality products - many with protected designation of origin (PDO) and protected geographical indication (PGI) labels or under certified organic regime-also in the livestock sector [5]. Livestock farms and livestock units (LU) distribution in Basilicata region are reported in Figures 1 and 2. LU is a reference unit that allows the aggregation of livestock from various species and age by using specific coefficients depending on nutritional or feed requirement of each type of animal.

The north-west area of Basilicata has the largest number of both livestock farms and LU, indicating the presence of small size farms. Conversely, an average of more than 100 LU per farm is found in three municipalities-Banzi, Irsina, and Lavello; this probably increases the livestock pressure on the environment. Farms number and their percentage distribution within LU classes in Basilicata are reported in Table 1 [5]. More than half of farms have a livestock size less than 10 LU, 33\% between 10 and $50 \mathrm{LU}$, and the remaining $9 \%$ holds a farm livestock asset of over $50 \mathrm{LU}$.

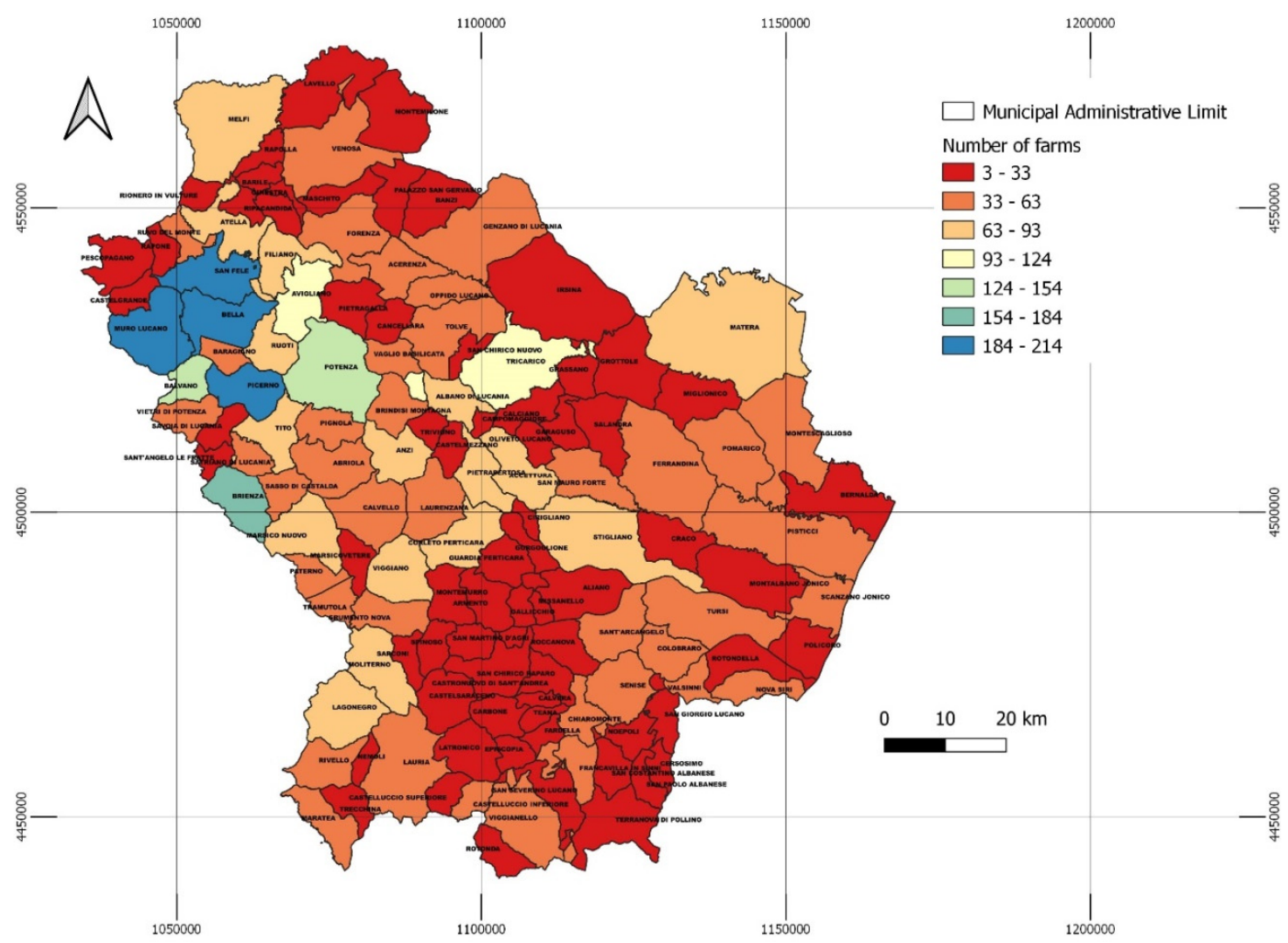

Figure 1. Livestock farms distribution in Basilicata region. 


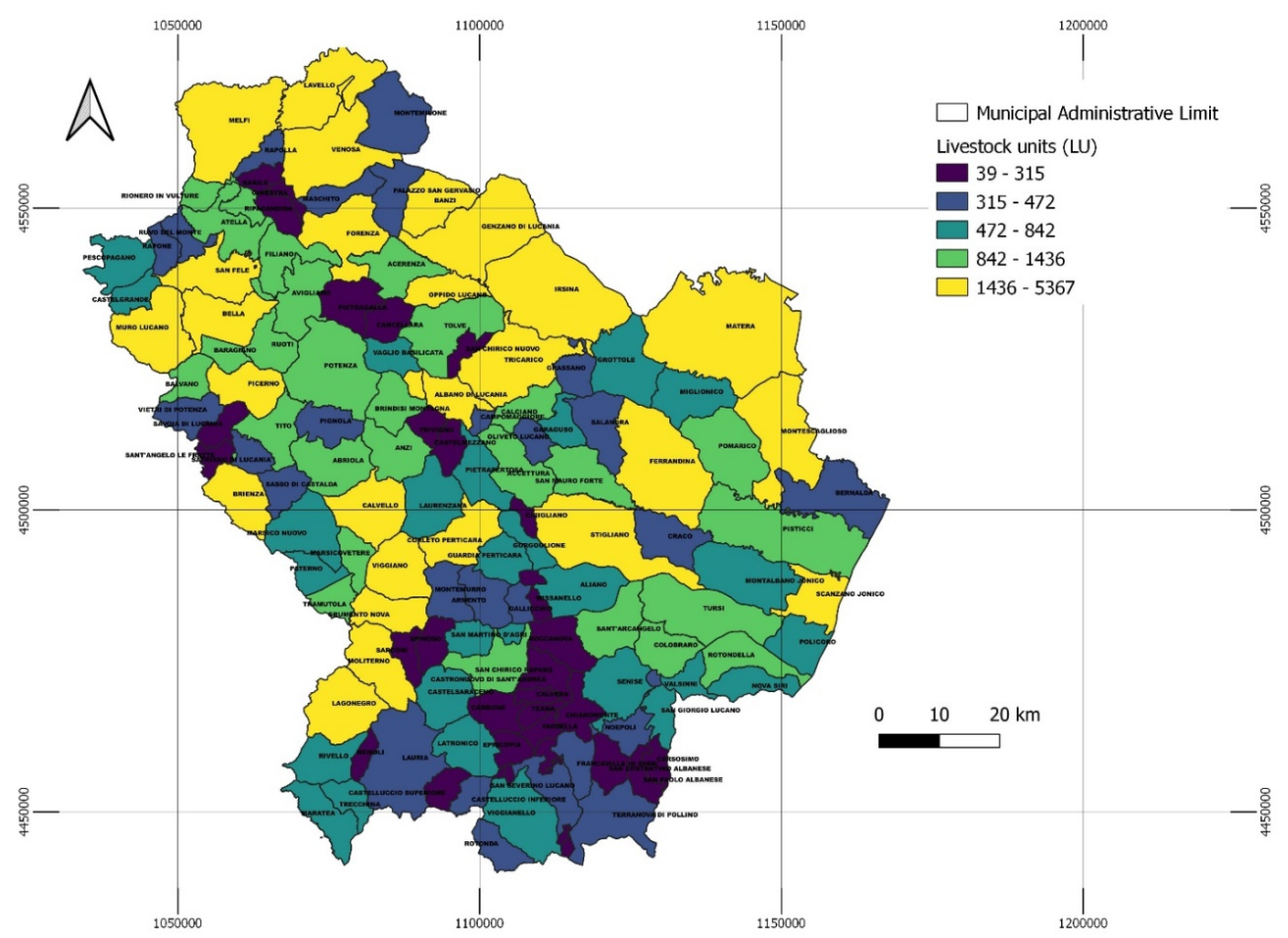

Figure 2. Livestock units (LU) distribution in Basilicata region.

Table 1. Farms number and its percentage distribution within livestock units (LU) classes in Basilicata region.

\begin{tabular}{ccc}
\hline LU Class & Farms Number & $\mathbf{\%}$ \\
\hline $1-9$ & 3299 & $57 \%$ \\
$10-49$ & 1919 & $33 \%$ \\
$50-99$ & 338 & $6 \%$ \\
$100-499$ & 172 & $3 \%$ \\
$>500$ & 17 & $0 \%$ \\
\hline TOTAL & 5745 & $100 \%$ \\
\hline
\end{tabular}

Four composting plants were built within different size farms that had joined technologies transfer/dissemination programs of some Italian (at national and regional level) and European projects. Precisely, the farms case studies were:

- The private farm “Iasi Agrizoo", located in Forenza (Basilicata, Italy, $40^{\circ} 51^{\prime} 37^{\prime \prime} \mathrm{N}, 15^{\circ} 51^{\prime} 16^{\prime \prime} \mathrm{E}$ );

- "Coop. Agrocarne Sud", a cooperative company that takes care of the breeding, slaughtering, and processing of pig meat nearby Latronico, a village in Potenza province (Basilicata, Italy, $\left.40^{\circ} 05^{\prime} 20^{\prime \prime} \mathrm{N}, 16^{\circ} 00^{\prime} 34^{\prime \prime} \mathrm{E}\right)$;

- "Nardozza and Rosa", a private cereal-livestock farm, located in Maschito (Basilicata, Italy, $\left.40^{\circ} 54^{\prime} 32^{\prime \prime} \mathrm{N}, 15^{\circ} 49^{\prime} 46^{\prime \prime} \mathrm{E}\right)$;

- "Santoro" farm, a private cereal-livestock runs directly by the owner, located within Potenza province (Bella, Basilicata, Italy, $40^{\circ} 43^{\prime} 29.8^{\prime \prime} \mathrm{N}, 15^{\circ} 35^{\prime} 53.4^{\prime \prime} \mathrm{E}$ ).

\subsection{Criteria for Choosing the Most Appropriate Composting Option within Demonstration Farms}

A detailed questionnaire was elaborated, as a preliminary survey, to evaluate the starting situation of each involved farms. Then, the questionnaire was given to the farmers who filled it. Some of the required information was the following: (a) Animal number, animal categories composition, type of breeding, etc., to calculate produced manure; (b) equipment availability for the preparation of the organic material mix and windrow/pile maintenance (tractor, mechanical shovel, digger, shredder, etc.); 
(c) availability of farm structures and/or spaces (dung heap with a well to collect leachate, uncovered or covered areas with free surfaces with or without waterproofing such as concrete slab, clay areas, horizontal silos, plastic sheeting for waterproofing the bottom in the absence of a concrete foundation, sheets of non-woven fabric for covering the heaps); (d) quantity and quality of eventual bulking agent-pruning residues, wood chips, straw - and/or easily compostable materials available on farm or recoverable from other nearby farms; (e) on-farm availability of irrigation pipes and/or air insufflation pumps; (f) availability and position of point of electricity and water distribution.

Data from the questionnaire were validated by a careful inspection and then elaborated to find the best composting option, i.e., the least expensive and impactful (low ex novo investments, transport costs zeroed or reduced, on-farm compost use, etc.). This was followed by the actual design and identification of other equipment and materials to be bought-for integrating what was already present in the company-and by the consequent cost plan.

The composting option carried out at "Santoro" farm was subjected to further analyses to assess the environmental, economic, and energy sustainability of the whole composting process by means of the following methodologies: Life cycle assessment (LCA), life cycle costing (LCC), and energy analysis (EA). This was a specific request by the regional project "COMPOSTA" in which the farm "Santoro" was involved. Particularly, a pre-intervention analysis - before the composting plant establishment-was performed in order to assess its current sustainability, in the broad sense. Then, the same type of analysis was carried out for the post-intervention phase-after the composting plant establishment-concerning the following process phases: Construction of the composting plant, acquisition of the bulking agent (chipboard, wood chips, straw, etc.), handling of the material to be composted (manure), composting process, storage of the compost produced, compost loading, and subsequent distribution in the field. Data needed for the study development were inventoried by means of a survey sheet, which was administered to the farmer. All materials and machines used in the pre and post-intervention phases were taken into account in the analysis (handling operations of the materials, transport, and distribution of compost, as well as the quantities of electricity, fuel, and of lubricant used). Details are reported in Tables 2 and 3.

Table 2. Life cycle inventory in pre-intervention analysis of "Santoro" farm. Data refer to a composting cycle that lasted one month.

\begin{tabular}{cc}
\hline Pre-Intervention Situation (Conventional) \\
\hline & Value per Cycle \\
\hline Stall cleaning & 80 \\
Machinery and farm tools (h) & 280 \\
Electricity (kWh) & 10 \\
\hline Scraper cleaning & 10 \\
Machinery and farm tools (h) & 6000 \\
Human labour (h) & 0.5 \\
Water (l) & \\
Diesel oil (kg) & 3.4 \\
Manure homogenization & 1.7 \\
Machinery and farm tools (h) & 9 \\
Human labor (h) & \\
Diesel oil (kg) & 4 \\
Manure loading & 2 \\
Machinery and farm tools (h) & 9 \\
Human labor (h) & 30 \\
Diesel oil (kg) & 15 \\
\hline Transport and distribution of manure & 79 \\
Machinery and farm tools (h) & \\
Human labor (h) & \\
Diesel oil (kg) & \\
\hline
\end{tabular}


Table 3. Life cycle inventory in post-intervention analysis of "Santoro" farm. Data refer to a composting cycle-lasted one month—and one ton of dry compost.

\begin{tabular}{|c|c|c|}
\hline \multicolumn{3}{|c|}{ Post-Intervention Situation (after the Composting Plant Establishment) } \\
\hline & Value per Cycle & Value per Ton \\
\hline \multicolumn{3}{|l|}{ Construction of the composting plant } \\
\hline Capital equipment $(\mathrm{kg})$ & 507 & 9.39 \\
\hline \multicolumn{3}{|l|}{ Wood chips transport } \\
\hline Machinery and farm tools (h) & 2 & 0.04 \\
\hline Human labor $(\mathrm{h})$ & 2.5 & 0.05 \\
\hline Diesel oil (kg) & 32 & 0.59 \\
\hline \multicolumn{3}{|c|}{ Wood chips distribution within the stall } \\
\hline Machinery and farm tools (h) & 1.5 & 0.03 \\
\hline Human labor $(\mathrm{h})$ & 3 & 0.06 \\
\hline Diesel oil (kg) & 5 & 0.09 \\
\hline \multicolumn{3}{|l|}{ Stall cleaning and pile preparation } \\
\hline Machinery and farm tools (h) & 2.5 & 0.05 \\
\hline Human labor $(\mathrm{h})$ & 4 & 0.07 \\
\hline Diesel oil (kg) & 9 & 0.17 \\
\hline \multicolumn{3}{|l|}{ Air insufflation and pile management } \\
\hline Machinery and farm tools (h) & 90 & 1.67 \\
\hline Electricity $(\mathrm{kWh})$ & 360 & 6.67 \\
\hline \multicolumn{3}{|l|}{ Platform unloading } \\
\hline Machinery and farm tools (h) & 3 & 0.06 \\
\hline Human labor $(\mathrm{h})$ & 3 & 0.06 \\
\hline Diesel oil (kg) & 11 & 0.20 \\
\hline \multicolumn{3}{|l|}{ Loading for transport } \\
\hline Machinery and farm tools (h) & 0.83 & 0.02 \\
\hline Human labor $(\mathrm{h})$ & 0.83 & 0.02 \\
\hline Diesel oil (kg) & 3 & 0.06 \\
\hline \multicolumn{3}{|l|}{ Transport and distribution of compost } \\
\hline Machinery and farm tools (h) & 8.2 & 0.15 \\
\hline Human labor $(\mathrm{h})$ & 4 & 0.07 \\
\hline Diesel oil (kg) & 22 & 0.41 \\
\hline
\end{tabular}

LCA methodology was applied following the standardized procedure from ISO 14040 and ISO $14044[19,20]$. It was aimed to define environmental sustainability of the two livestock waste management options. For the development of the whole assessment, both the functional unit (FU) and the system boundaries were defined. The FU in LCA provides a reference to which the inputs and outputs of the inventory are related and allows the comparison between systems or alternatives $[19,20]$. The function of the plant under study was to produce compost from manure. Therefore, the basis for the comparison of the two options, named the FU of the service delivered, was defined as the production of one ton of compost with a 70\% dry matter, as reported also in other studies [21-23]. In order to meet the objectives of the present study, the system boundaries in the pre-intervention phase included the stall cleaning, scraper cleaning, manure homogenization, manure loading, transport, and distribution of manure; while in the post-intervention phase, they included the following operations: Construction of the composting plant; wood chips transport and their distribution within the stall; stall cleaning and pile preparation; composting process (air insufflation and pile management); compost loading for transport and its final transport and distribution. The environmental assessment was carried out using SimaPro8.02 software, with the problem oriented CLM method developed by the Institute of Environmental Sciences of the University of Leiden [24]. Particularly, global warming potential (GWP), expressed as $\mathrm{kg}$ of $\mathrm{CO}_{2}$ eq emitted per ton of compost produced, was taken into account as reference parameter for environmental impacts. 
The EA, performed according to the principle of energy matter inputs (EMI), allowed to express in MJ per ton of compost produced the consumption of energy linked to all the above-described phases for the preparation of the composting plant. Energy values of unit inputs were obtained by multiplying each input by its own coefficient of equivalent energy factors taken from the literature (concrete: $3 \mathrm{MJ} \mathrm{kg}^{-1}$; fuel: $46.2 \mathrm{MJ} \mathrm{kg}^{-1}$; iron: $54.39 \mathrm{MJ} \mathrm{kg}^{-1}$; machinery: $80 \mathrm{MJ} \mathrm{kg}^{-1}$; plastic: $83.68 \mathrm{MJ}$ $\mathrm{kg}^{-1}$; electricity: $10.5 \mathrm{MJ} \mathrm{kW}^{-1}$; human labor: $1.95 \mathrm{~h}^{-1}$ ) [25-28].

The life cycle costing (LCC) of the production of 1 ton of compost was used for the production costs analysis, given that the main research goal was the feasibility assessment and the economic convenience of building small composting plants. In order to analyze the amount of the total cost of 1 ton of compost, as reported in Ruggieri et al. [29] and in Mu et al. [30], the lifespan of the composting plants (15 years) was considered and each value of the annual costs, whose current prices referred to 2017, was indexed and aggregated using a rate anticipation $\left(1 / \mathrm{q}^{\mathrm{n}}\right)$, where $\mathrm{n}$ refers to the individual years of the lifespan of the composting plants $(n=1, \ldots, 15)$ and $q$ represents an indexing factor, whose interest rate was assumed to be equal to $2 \%$. All values of the indexed costs were then added together. Further details on the above-cited methodologies are reported in Pergola et al. [31,32].

\section{Results and Discussion}

According to the most recent agriculture census [5], livestock sector of Basilicata generally follows trends seen for Europe and Italy highlighting, in detail, several changes such as reduction of farm number and susceptible increase in farm average size; increase in unit production; increase of animal feed purchases to satisfy —in both quantitative and qualitative terms - the increasing animal needs; etc. At the same time, an expansion of the corporate workload has been observed causing a downward trend in the use of local fodder surfaces and the contraction of the working times per unit area. With respect to livestock structures, housing systems—-which require waste management under liquid form - have been established in recent years. This has caused many management problems and various drawbacks such as reduction in use efficiency of nutrients contained in animal waste; particularly persistent and unpleasant odors; and potential pollution of water bodies. In some cases, these drawbacks were aggravated by the underestimation, during the design phase, of the waste volumes to be stored or/and the failure to adapt waste disposal structures within the farm, due to the high costs, after the increase in the number of livestock.

\subsection{Preliminary Survey Results and Operative Choices}

According to the data collected by means of the preliminary survey, the private farm "Iasi Agrizoo" has a total agricultural surface of 400 hectares; 330 hectares of these are arable soil cultivated with wheat, barley, fodder, hay, and stable meadows (Figure 3). The farm center is composed by large sheds occupying about $20,000 \mathrm{~m}^{2}$. They are used as a shelter for 650 dairy cattle divided into 100 heifers, 50 cows in dry, 400 lactating cows, and 100 weaning calves. The breeding produces 3200 tons of milk and 40 tons of meat yearly. Manure is firstly separated into a thin and thick fraction. The separate liquid fraction feeds a biogas plant producing electricity sold entirely to the electricity manager. The separate solid is equal to $2555 \mathrm{~m}^{3}$ per year and is partly used as litter in the bunks and partly in the field. Taking into account the re-employment within the farm, "Iasi Agrizoo" can allocate about $7 \mathrm{~m}^{3}$ of separated solid to composting daily. Other organic matrices available within the farm itself-such as straw, unifeed waste, deteriorated forage — and indicatively quantifiable in not more than $10 \%$ the total annual separated solid, can be beneficially used for composting. 


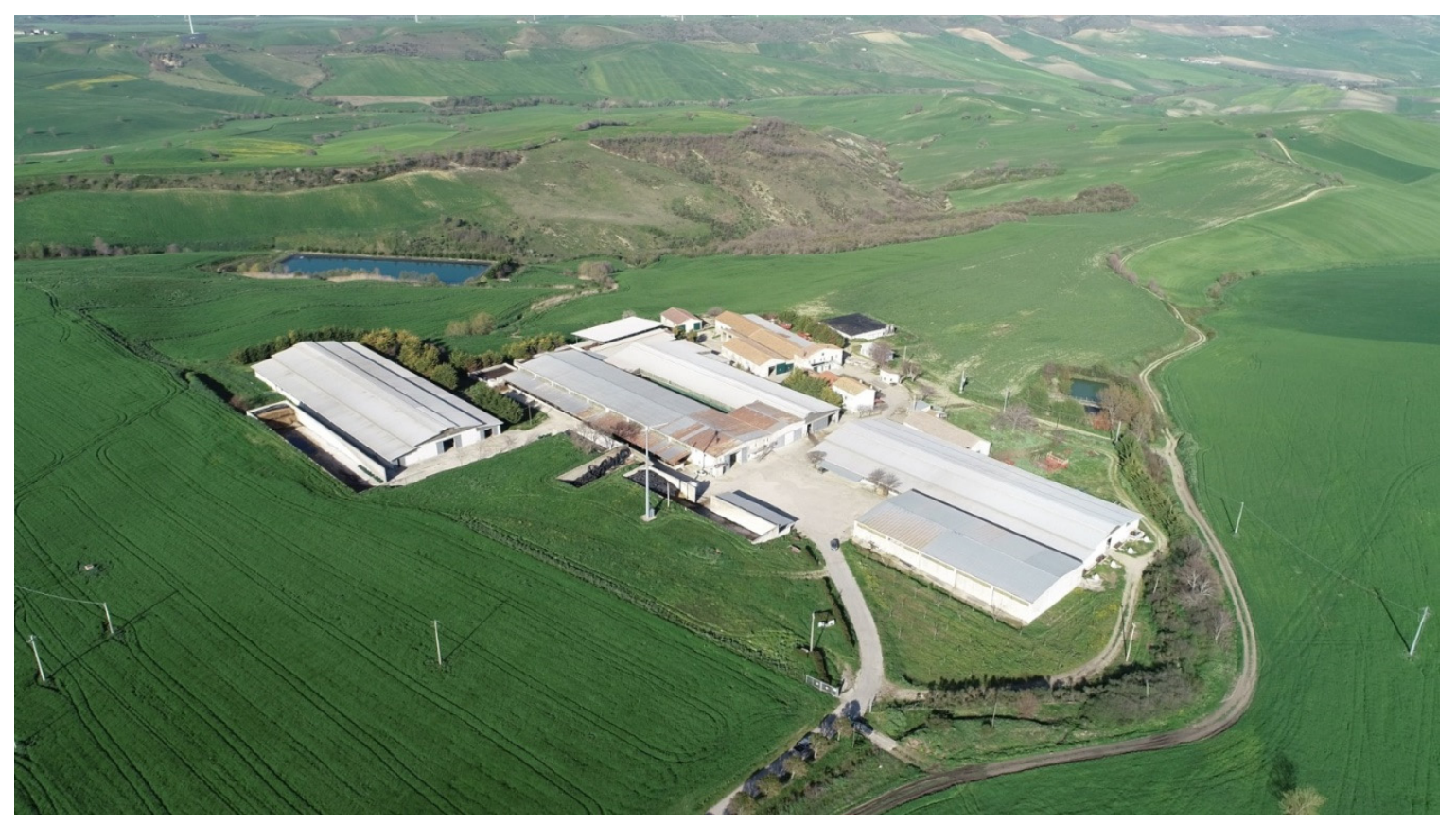

Figure 3. The private farm "Iasi Agrizoo"; the farm's center.

Considering the preliminary analysis on the type and extent of the farm waste to be managed, the static windrow with active aeration was suggested as composting method. This is a low-cost composting technology, which allowed the total recovery of the pre-existing structures within "Iasi Agrizoo" (waterproofed area covered by a roof and served by a point of distribution of electricity). This strategy had the following functions: a) To sanitize and further dry the separated solid to be put as bedding in the bunks; b) to compost part of the separated solid in the presence of litter straw and other farm waste such as deteriorated fodder, moldy straw, etc. The composting mixture was placed on ventilation pipes, suitably drilled and positioned, and fed by a fan (Figure 4). A digital timer allowed air injection $\left(0.43 \mathrm{~m}^{3} \mathrm{~s}^{-1}\right)$ for 5 min every hour during the first 20 days of the process. Air insufflation for aerobic composting systems is essential for providing metabolic oxygen, controlling temperature variations inside the heap, minimizing odors, and removing water. The use of forced aeration systems for composting facilitates and improves the controlled and uniform distribution of air in the heap, significantly improving the quality of the final compost.

Technical features of the composting module were the following: Power supply and control panel certified in accordance with the law, equipped with a magnetothermal switch, timer, and 220V/380V socket (220V service socket; $380 \mathrm{~V}$ fan supply); $2.5 \mathrm{~kW}$ high-pressure power $\left(0.43 \mathrm{~m}^{3} \mathrm{~s}^{-1}\right)$ and ventilation cable; main duct ( $1110 \mathrm{~mm}$ PVC pipes) for air insufflation system with two secondary ducts in polyethylene $(\varnothing 66 \mathrm{~mm})$, length $8 \mathrm{~m}$ with end cap. The temperature was monitored daily by means of a digital probe with a $1.5 \mathrm{~m}$-foot stem (Figure 5). An operator recorded the temperature values from six different point samples within the pile, at two depths $(40 \mathrm{~cm} ; 90 \mathrm{~cm})$. The composting process was stopped when the pile temperature remained more or less constant, after the turning and wetting of some sample parts of the pile. In any case, the time for obtaining mature compost was about three months. In this study, temperature was taken as guide parameter to control composting process evolution and to evaluate compost maturity. Other simple and empirical parameters, based on own senses (touch, smell, sight), can be used to assess the quality of the composting process. Samples should be taken from different pile locations, at $30-40 \mathrm{~cm}$ depth in the compost pile, and mixed together to make a representative sample. Observations have to be carried out on fresh samples or samples stored at $4{ }^{\circ} \mathrm{C}$ for a couple of days. Compost changes color during the process passing from a variegated color, due to the different starting matrices, to a more homogeneous tint, until a brown or black color of the mature compost. Disagreeable odors indicate an incorrect process management, while a mature 
compost smells of woodland. Again, a crumbly structure with some wooden pieces is indicative of a mature compost. In any case, it is strongly advisable to make a complete physico-chemical analysis of the final compost in order to standardize the product and to guarantee its quality. The analysis should be performed at least twice a year on compost obtained from similar raw materials.

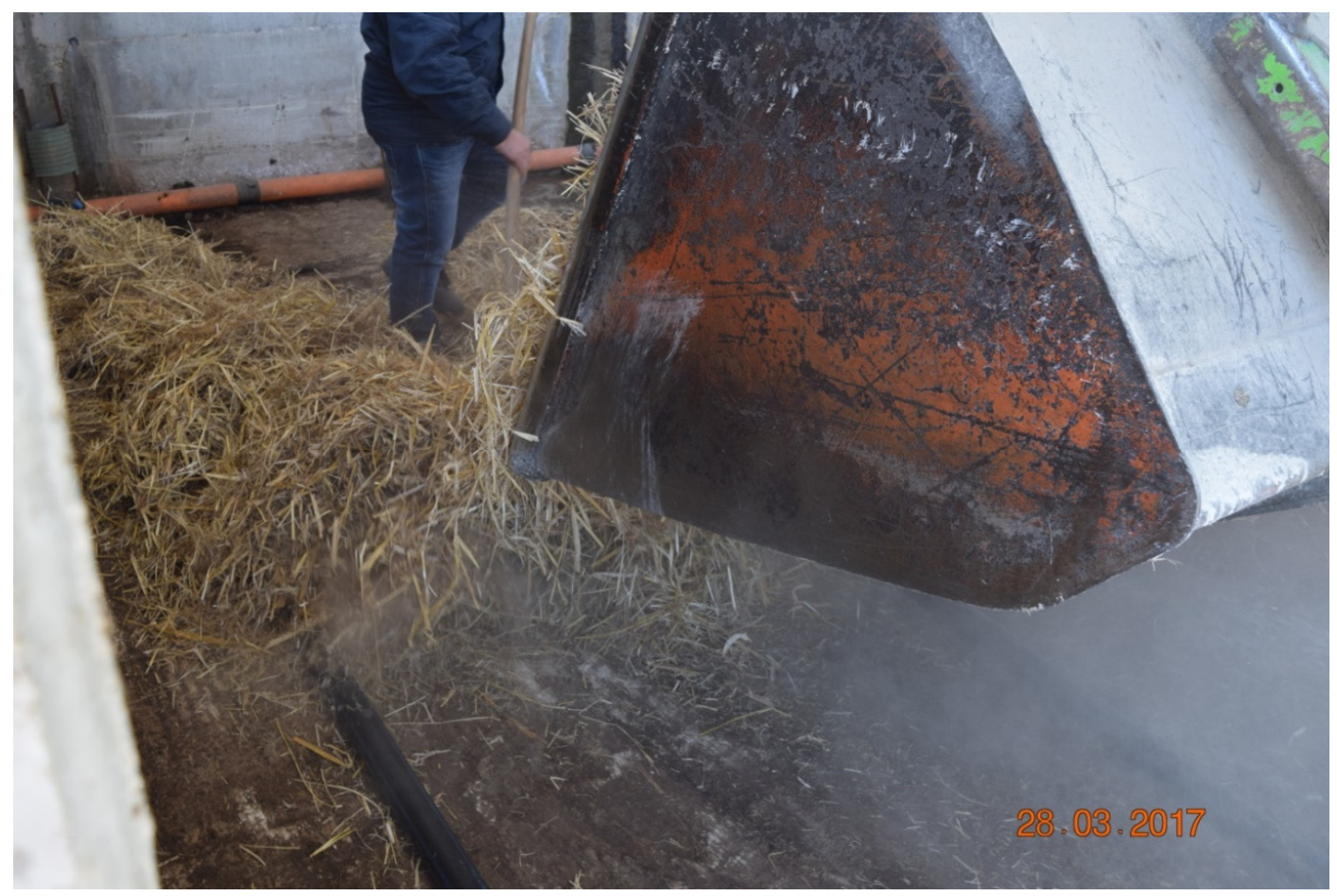

Figure 4. The composting mixture placing on the ventilation pipes.

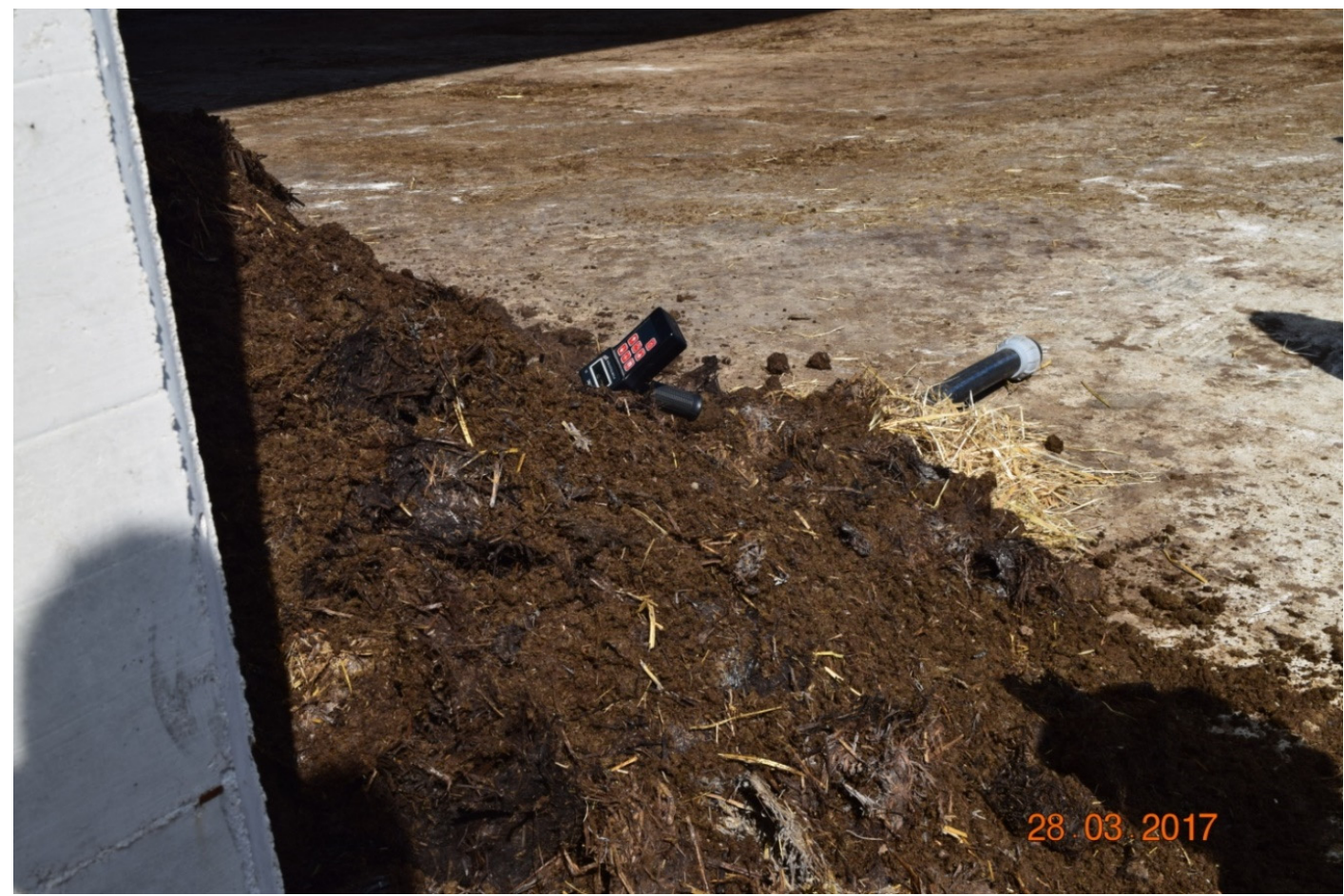

Figure 5. Temperature measurements performed during the composting process by means of a digital probe. 
This demonstration composting plant was able to transform approximately $100 \mathrm{~m}^{3}$ per year of separated solid into mixed compost (v/v: $60 \%$ separated solid $+40 \%$ bulking agent). This compost was distributed within "Iasi Agrizoo" farm-on fodder and cereals—at doses ranging from 10 to 12 tons per hectare, during the seedbed preparation operations.

The type of waste produced within the cooperative "Coop. Agrocarne Sud" is slurry $\left(135 \mathrm{~m}^{3}\right.$ per week) that ends up in collection tanks in which the first separation occurs by flotation and rolling of the solid material—called "cruschello"; the latter is collected in heaps as a palatable material. The liquid fraction is directed to the company biogas plant through pipes; the digestate leaving the digester is then separated into a solid fraction and a liquid one. The solid digestate is placed in the pit where it undergoes maturation before its use. The liquid fraction undergoes a treatment in the company purification plant before to be placed in the municipal sewer system. Annual average livestock number is 2000. The cooperative characteristics can be summarized as follows:

- Training system: Intensive;

- Average productions of dejections—as it is—per week: $7020 \mathrm{~m}^{3}$;

- Average production of "cruschello" per week: $130 \mathrm{~m}^{3}$ (40 tons);

- Average production of solid separated per week: $364 \mathrm{~m}^{3}$ (234 tons);

- $\quad$ Surface of the ex-drying beds: $1200 \mathrm{~m}^{2}$;

- Availability of mechanical means (third, shovel, manure spreader, etc.): Tractor with loader.

At "Coop. Agrocarne Sud", composting in static windrow with active aeration was proposed, similarly to what indicated for "Iasi Agrizoo" farm. Particularly, this low-cost composting plant was made in one ex-drying tank within the cooperative, according to the drawing reported in Figure 6.

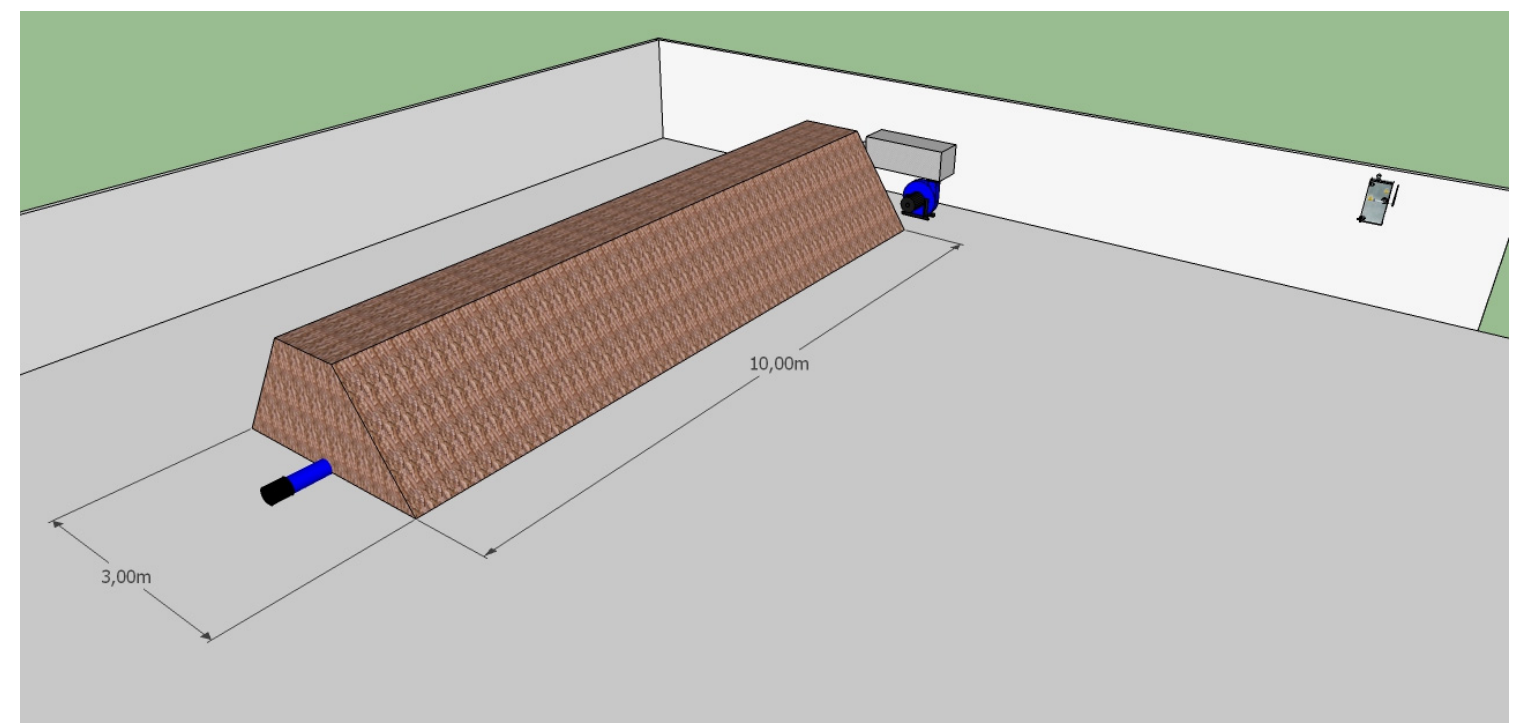

Figure 6. The composting system project at the cooperative "Coop. Agrocarne Sud". The pile was $1.5 \mathrm{~m}$ high.

The plant consisted of a $2.2 \mathrm{~kW}$ power fan with a flow rate of $0.43 \mathrm{~m}^{3}$ per second applied for $5 \mathrm{~min}$ every hour during the first 20 days of the process, an electrical panel equipped with a timer, and a $90 \mathrm{PE}$ pipe for a length of $13 \mathrm{~m}$. The working capacity was about $18 \mathrm{~m}^{3}$ allowing the farm to produce about 10 tons of finished product per composting cycle. Considering an average duration of the bio-oxidative phase of 60 days, the demonstration plant allowed to obtain about 60 tons of mature compost per year. The separated solid from pig slurry was mixed with about $8 \mathrm{~m}^{3}$ of bio-triturate with a structuring function and corresponding to about $40 \%(v / v)$ of the mixture (Figure 7$)$. Once prepared, the composting pile was covered by a non-woven sheet to protect the materials from rain and solar radiation, without compromising the gas exchanges (Figure 8). Pile temperature was measured daily as described for 
"Iasi Agrizoo" farm. The time for obtaining mature compost was three months. In agricultural lands nearby the cooperative "Coop. Agrocarne Sud", in addition to forage and cereal crops, several hectares of vineyards are cultivated. In the case of the vine, the post-harvest phase, especially when harvest occurs precociously, appears to be the optimal moment for compost distribution at the recommended quantities of around 10 tons per hectare. In any case, soil characteristics have to be taken into account in the compost distribution plan.

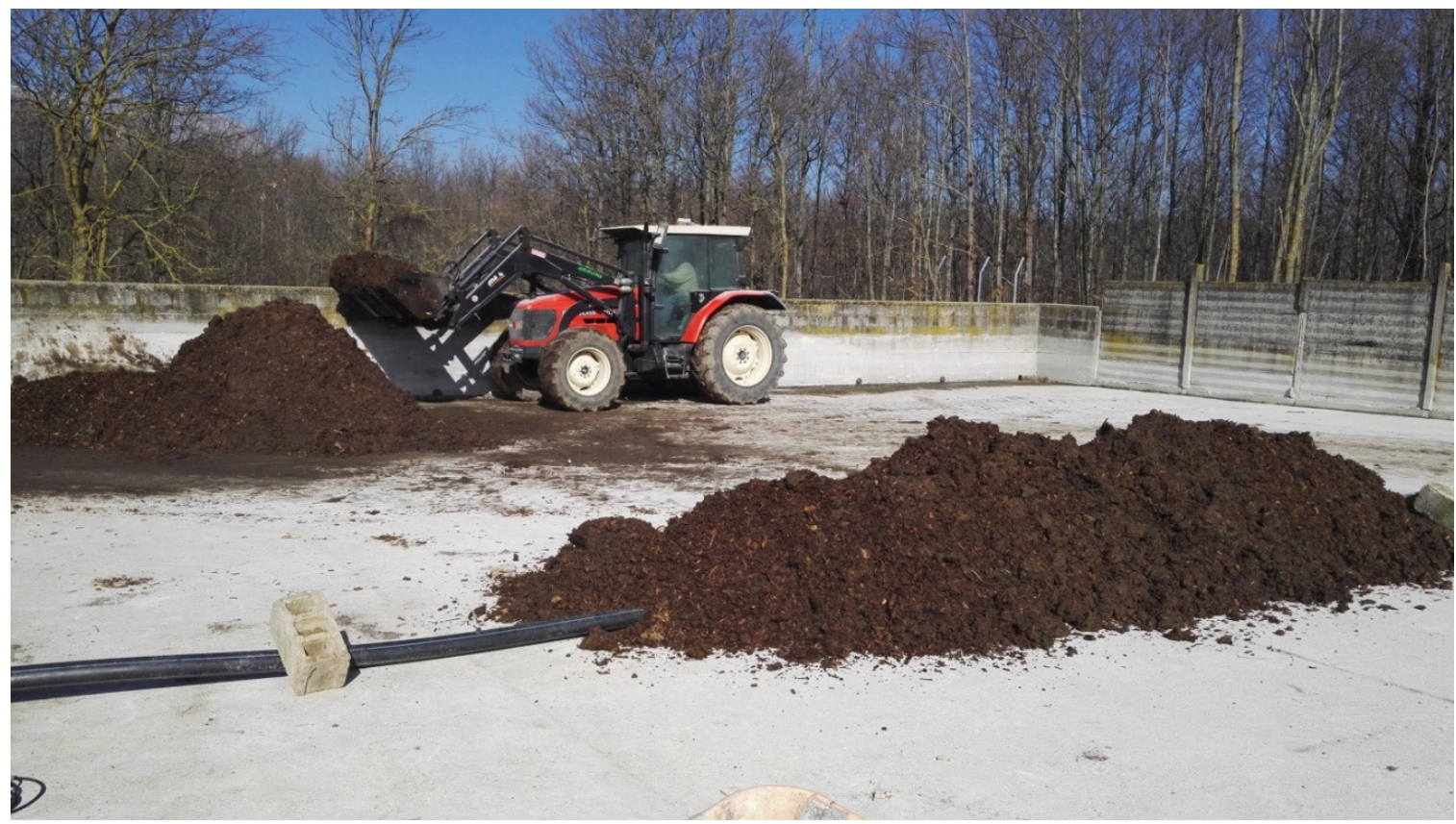

Figure 7. The preparation of the composting mixture and its placing on the ventilation pipe at the cooperative "Coop. Agrocarne Sud".

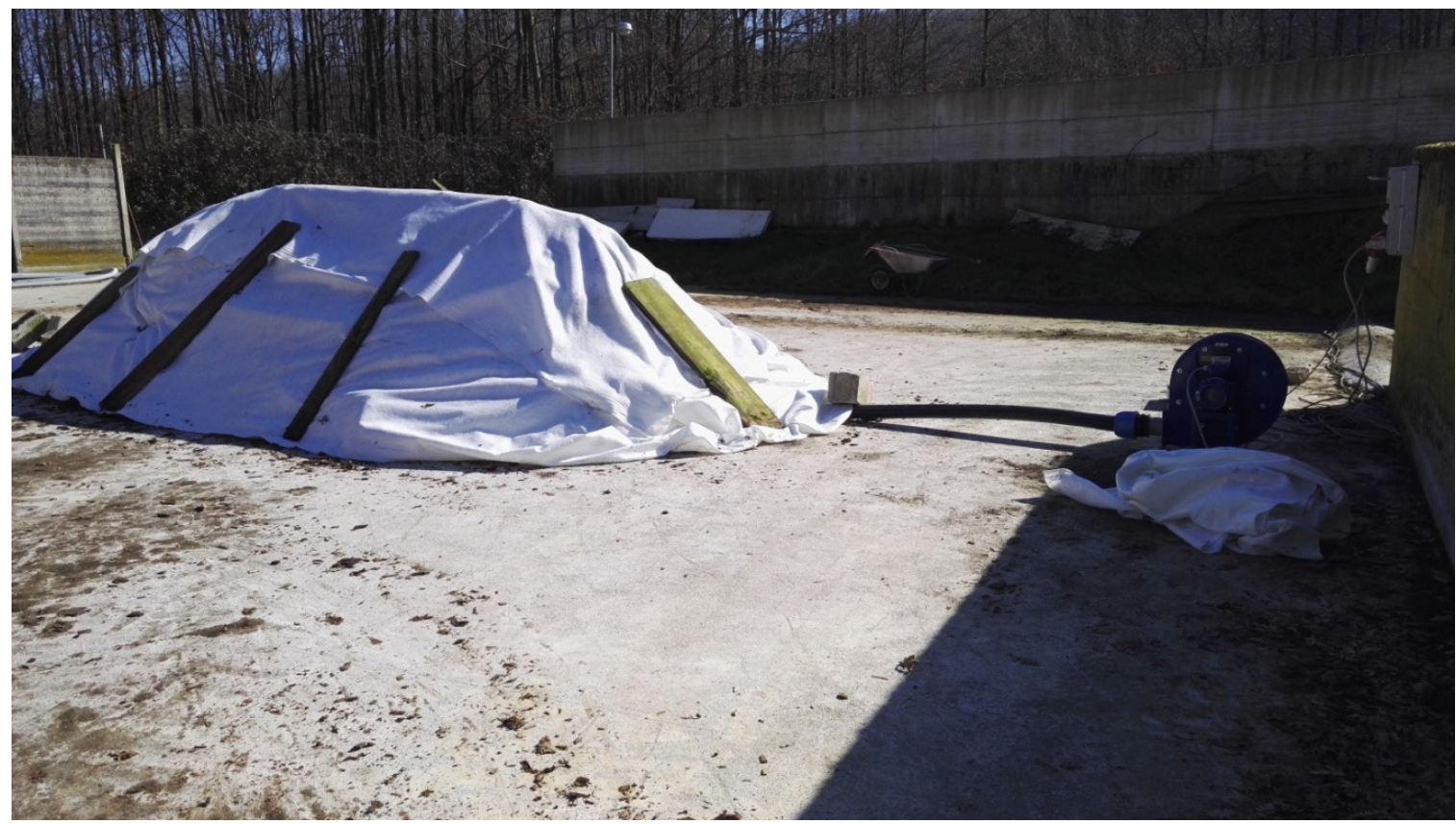

Figure 8. The composting pile covered by the non-woven sheet at the cooperative "Coop. Agrocarne Sud". 
"Nardozza and Rosa" farm has about 250 hectares of agricultural land planted with fodder, grain cereals, and pastures. A sheepfold of about $850 \mathrm{~m}^{2}$ is located in the farm center. The livestock consistency is of about 600 heads of Italian Merino-derived breed (350 sheep and the remaining part composed by rams, lambs for meat, and breeding animals). The breeding system is semi-extensive. The animals are raised in stalls on straw litter, which is removed when reaching the level of the front of the manger. The declared annual quantities of material able to be shoveled are $440 \mathrm{~m}^{3}$. The removal of the litter is performed about four times a year with the mechanical shovel available in the farm. The farm has a manure spreader with side discharge, and it can easily access the use of rear discharge manure spreader.

A composting technology in static heaps, with passive aeration, was realized in an area adjacent to the sheepfold. The linear pile was made with the help of the rear discharge manure spreader (Figure 9).

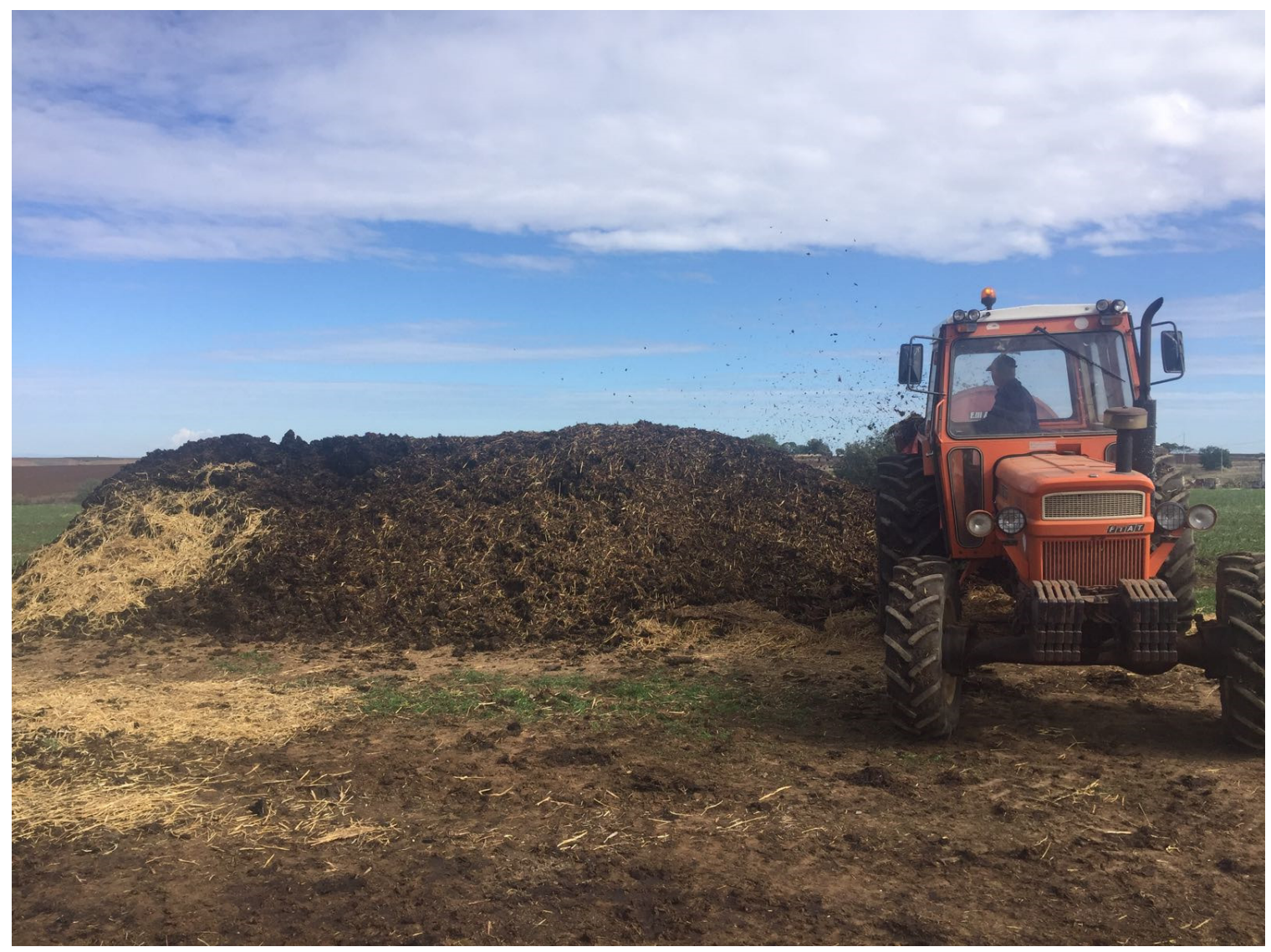

Figure 9. The composting pile preparation utilizing the manure spreader at "Nardozza e Rosa" farm.

The pile was built on a bed of straw placed directly on the ground, as allowed by the Italian law (Decree 7 April 2006, implemented in Basilicata with the D.G.R. n. 413, 19 April 2016) in the presence of not very permeable soil. The straw bed represented an initial layer of cellulosic material with a structuring function for the air passive inlet, and an "insulator" and "buffer" function against any excess leachate leaking from the organic matrices. Then, the mixture composed by sheep manure and additional "structuring" material (straw, about 30\% by volume) was prepared. Particularly, sheep manure was very rich in straw and stabilized for 90 days in the housing stables of the existing sheepfold; this assured the correct performance of the composting process. The starting matrices, about $30 \mathrm{~m}^{3}$, were mixed with the aid of a side discharge manure spreader, which was also used to create a single windrow of about $15 \mathrm{~m}$ in length, a width of $2 \mathrm{~m}$, and an average height of $1.5 \mathrm{~m}$. The heap dimensions resulted from the material amount deriving from a cycle of straw litter removal. During the bio-oxidative phase of the composting process, a non-woven cover was used to insulate the 
windrow without compromising gas exchange and avoid water losses (essential steps for the quality of the final compost). The pile temperature was daily measured in six different point samples at two depths $(40 \mathrm{~cm} ; 90 \mathrm{~cm})$, using a portable digital device $1.5 \mathrm{~m}$ long. Also in this case, the temperature was used as a guiding parameter of the composting process. The composting cycle lasted six months. Within "Nardozza and Rosa" farm, compost was distributed to the fodder at doses of around 10-15 tons per hectare per year, coinciding with seedbed preparation (autumn). Compost could have fruitful application in numerous vineyards spread in the rural areas close to the farm.

"Santoro" farm has a total agricultural surface of 24.3 hectares seven of which are covered by woods. The breeding is of Friesian dairy cattle for a total of 49 heads including 31 cows, 13 heifers, and 5 calves. Housing is fixed. Livestock waste is removed twice a day with a scraper and the use of straw is limited to the beds of lactating cows. Waste production is approximately $708 \mathrm{~m}^{3}$ year $^{-1}$ of material able to be shoveled and $423 \mathrm{~m}^{3}$ year $^{-1}$ of slurry. The latter is introduced into a $16 \mathrm{~m} \times 4 \mathrm{~m} \times$ $4 \mathrm{~m}$ collection tank, which does not fully respond to the current farm needs and leads to management problems, especially in the winter period. Livestock waste is distributed in the field by tank-wagon after homogenization.

Aerated static pile was the most appropriate composting option. The farm improvement intervention has been realized recovering the pre-existing manure storage facilities/spaces. Particularly, the plant consists of a storage concrete platform and a composting cell of $50 \mathrm{~m}^{2}$ with retaining walls high $2 \mathrm{~m}$, built ex novo, and it is free of cover (Figure 10). Such a small number of modifications can allow the farmer to eventually return to the pre-intervention situation without additional costs. The composting plant, whose total size is about $210 \mathrm{~m}^{2}$, can annually process $1800 \mathrm{~m}^{3}$ of starting matrices and produce around 600 tons of compost from manure. With respect to the management of the stall, only two new actions were introduced: Direct addition of shredded wood/sawdust as bedding for the animals and its cleaning with mechanical shovel. The materials composted in the plant were the cattle manure from the farm, bedding from the stable, and biomass resulting from cleaning and maintenance of Basilicata woods. The temperature of the pile was measured as described for the other demonstration cases. The duration of the composting cycle was one month.

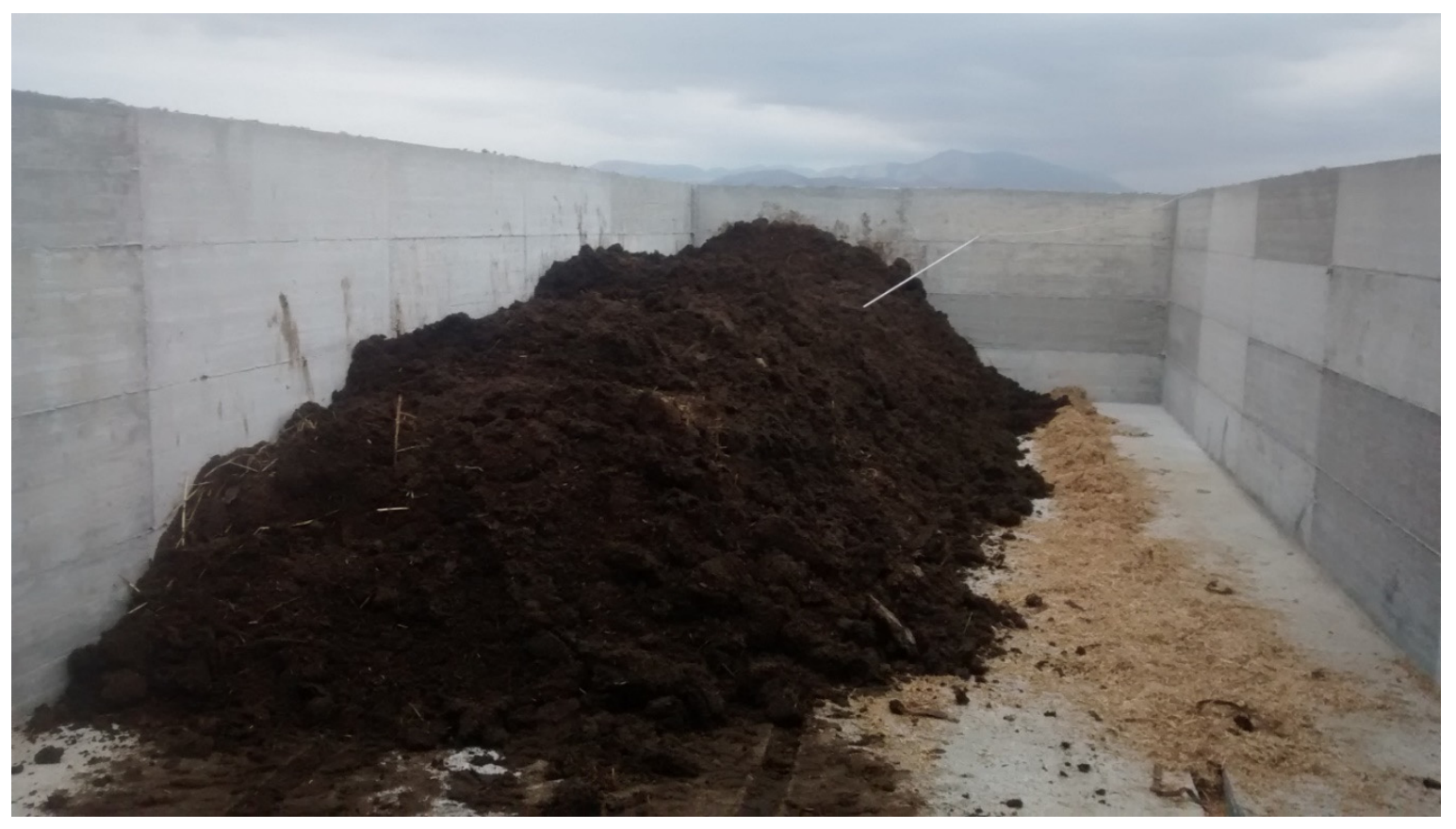

Figure 10. The composting pile preparation at "Santoro" farm.

A summary of the characteristics of the farms involved in the study and of the solutions adopted for composting are reported in Table 4. 
Table 4. Synthesis on farms characteristics and composting options.

\begin{tabular}{|c|c|c|c|c|}
\hline & Iasi Agrizoo & $\begin{array}{l}\text { Coop. Agrocarne } \\
\text { Sud }\end{array}$ & $\begin{array}{l}\text { Nardozza and } \\
\text { Rosa }\end{array}$ & Santoro \\
\hline Farm location & $\begin{array}{c}\text { Italy-Basilicata } \\
\text { region- Forenza } \\
\text { (PZ) } 40^{\circ} 51^{\prime} 37^{\prime \prime} \mathrm{N}, \\
15^{\circ} 51^{\prime} 16^{\prime \prime} \mathrm{E}\end{array}$ & $\begin{array}{c}\text { Italy-Basilicata } \\
\text { region- Latronico } \\
(\mathrm{PZ}) 40^{\circ} 05^{\prime} 20^{\prime \prime} \mathrm{N}, \\
16^{\circ} 00^{\prime} 34^{\prime \prime} \mathrm{E}\end{array}$ & $\begin{array}{c}\text { Italy-Basilicata } \\
\text { region- Maschito } \\
\text { (PZ) } 40^{\circ} 54^{\prime} 32^{\prime \prime} \mathrm{N}, \\
15^{\circ} 49^{\prime} 46^{\prime \prime} \mathrm{E}\end{array}$ & $\begin{array}{l}\text { Italy-Basilicata } \\
\text { region- Bella (PZ) } \\
\quad 40^{\circ} 43^{\prime} 29.8^{\prime \prime} \mathrm{N}, \\
15^{\circ} 35^{\prime} 53.4^{\prime \prime} \mathrm{E}\end{array}$ \\
\hline Farm productions & dairy cattle & pork & $\begin{array}{l}\text { dairy sheep and } \\
\text { lamb }\end{array}$ & dairy cattle \\
\hline Breeds bred & $\begin{array}{l}\text { cattle (Friesian and } \\
\text { Jersey) }\end{array}$ & $\begin{array}{l}\text { pigs (suino nero } \\
\text { Lucano) }\end{array}$ & $\begin{array}{c}\text { sheep } \\
\text { (Merino-derived) }\end{array}$ & cattle (Friesian) \\
\hline $\begin{array}{l}\text { Number of raised } \\
\text { animals }\end{array}$ & 650 & 2000 & 600 & 49 \\
\hline $\begin{array}{l}\text { Main by-product to } \\
\text { be used for } \\
\text { composting }\end{array}$ & $\begin{array}{l}\text { solid separate from } \\
\text { cattle manure }\end{array}$ & $\begin{array}{l}\text { solid separate from } \\
\text { pigs' slurry }\end{array}$ & sheep manure & cattle manure \\
\hline $\begin{array}{l}\text { By-product } \\
\text { quantity }\end{array}$ & $2555 \mathrm{~m}^{3}$ year $^{-1}$ & $364 \mathrm{~m}^{3}$ year $^{-1}$ & $440 \mathrm{~m}^{3}$ year $^{-1}$ & $708 \mathrm{~m}^{3}$ year $^{-1}$ \\
\hline $\begin{array}{l}\text { Others raw } \\
\text { materials }\end{array}$ & $\begin{array}{c}\text { straw, unifeed } \\
\text { waste, deteriorated } \\
\text { forage }\end{array}$ & cruschello & straw & straw \\
\hline $\begin{array}{l}\text { Others raw } \\
\text { materials quantity }\end{array}$ & $\begin{array}{c}\text { variable } \\
\left(<250 \mathrm{~m}^{3} \text { year }^{-1}\right)\end{array}$ & $130 \mathrm{~m}^{3}$ year $^{-1}$ & - & - \\
\hline $\begin{array}{l}\text { concrete platform } \\
\text { for composting }\end{array}$ & YES & YES & $\mathrm{NO}$ & YES \\
\hline $\begin{array}{l}\text { Machinery for } \\
\text { composting }\end{array}$ & $\begin{array}{c}\text { mechanical shovel } \\
\text { (bobcat) }\end{array}$ & $\begin{array}{l}\text { tractor with a } \\
\text { shovel }\end{array}$ & $\begin{array}{l}\text { tractor with a } \\
\text { shovel, manure } \\
\text { spreader }\end{array}$ & $\begin{array}{c}\text { mechanical shovel } \\
\text { (bobcat) }\end{array}$ \\
\hline $\begin{array}{c}\text { Composting } \\
\text { typology }\end{array}$ & aerated static pile & aerated static pile & static pile & aerated static pile \\
\hline $\begin{array}{l}\text { Capacity of the } \\
\text { demonstration } \\
\text { composting plant }\end{array}$ & $100 \mathrm{~m}^{3}$ year $^{-1}$ & $72 \mathrm{~m}^{3}$ year $^{-1}$ & $60 \mathrm{~m}^{3}$ year $^{-1}$ & $1800 \mathrm{~m}^{3}$ year $^{-1}$ \\
\hline
\end{tabular}

\subsection{Composting Versus Conventional Manure Treatment Methods: A Further Study on "Santoro" Farm}

The results of the energy, environmental, and economic analysis performed within "Santoro" farm are reported in Table 5. Against a slight increase in energy consumption $(+10 \%)$, the manure composting solution impacted less $(-6 \%)$ and showed lower costs $(-37 \%)$ than the conventional management with scraper. The higher energy consumption, measured in the post-intervention situation, was due to the energy incorporated in concrete used for the construction of the composting plant (Figure 10). In the composting solution, pile management (26\%) and chips transport to the farm (26\%) were the most impactful actions. Wood chips acquisition/transport to the farm was also the most expensive phase (59\%) within the compost alternative being chips price equal to $9.50 € \operatorname{ton}^{-1}$ (on dry matter basis), excluding the loading phase and the transport to the field. In the conventional management, the most impactful (87\%) and expensive (81\%) operations were the stall cleaning, the transport of manure, and its distribution in the field. 
Table 5. Energy, environmental, and economic analysis, performed within "Santoro" farm, before (pre-intervention situation) and after the composting plant establishment (post-intervention situation). Data refer to a composting cycle that lasted one month.

\begin{tabular}{cccc}
\hline Operative Activity & MJ & kg (CO $\mathbf{~ e q})$ & Euro \\
\hline Pre-intervention situation (conventional) & & \\
\hline Stall cleaning & 3978 & 225 & 151 \\
Scraper cleaning & 26 & 2 & 65 \\
Manure homogenization & 532 & 44 & 36 \\
Manure loading & 508 & 42 & 56 \\
Transport and distribution of manure & 4572 & 382 & 500 \\
\hline Total & 9616 & 695 & 808 \\
\hline Post-intervention situation (after the composting plant establishment) & \\
\hline Construction of the composting plant & 3368 & 105 & 44 \\
Wood chips transport & 1629 & 170 & 300 \\
Wood chips distribution within the stall & 304 & 26 & 29 \\
Stall cleaning and pile preparation & 505 & 43 & 36 \\
Air insufflation and pile management & 2862 & 171 & 63 \\
Platform unloading & 137 & 8 & 36 \\
Loading for transport & 167 & 14 & 10 \\
Transport and distribution of compost & 1525 & 119 & 131 \\
\hline Total & 10497 & 656 & 649 \\
\hline Total for 1 ton of dry compost produced & 208 & 13 & 13 \\
\hline
\end{tabular}

The comparison of the pre-intervention situation (conventional) and the post-intervention with compost production - by means of LCA, EA, and LCC methodologies-clearly gave indications on which are the strengths and weaknesses of the different manure managements. This can allow one to identify where it is possible to intervene in order to contain impacts or enhance positive effect, guiding farmers choices. In this case, it would be desirable to find the bulking agent within "Santoro" farm (i.e., residues from woods) or from other nearby farms to break down impacts due to wood chips acquisition/transport (Table 5). In addition to the lower environmental impact found (656 kg $\mathrm{CO}_{2}$ eq versus $695 \mathrm{~kg} \mathrm{CO}$ eq of the manure conventional management), on-farm composting should be recommended thanks to the several agronomical benefits and defense capacity from pests testified by many studies $[14,33,34]$. However, the most noticeable result coming from this experience was the economic savings of the alternative manure management (Table 5) and the compost added value. According to Italian law [35], compost coming from a mixture of manure and other organic material can be classified as mixed composted soil conditioner and counted among the types of fertilizers allowed in agriculture. Therefore, farms producing compost could join the list of fertilizer manufacturers and place the product on the market at very attractive prices $\left(25 € \mathrm{~m}^{-3}\right)$, able to cover waste management costs, and in some cases, assure an interesting farm profit.

\subsection{Dissemination activities}

Several meetings were organized at the demonstration farms together with the Regional Extension Services (ALSIA). These dissemination activities allowed to show to a wide range of stakeholders (farmers, technicians, civil servants, freelancers, students) the composting options chosen under different and specific farm contexts. These meetings were also a good occasion to demonstrate the feasibility of the small-scale composting and of the process control by easily measurable parameters such as temperature. 


\section{Conclusions}

In this paper, the design of simplified composting technology systems was proposed in different farm contexts to provide enough case studies to cover as much possible actual situations. These farm size installations - easily reproducible also in other similar contexts by low cost techniques-seem to be an opportune and more sustainable way (in both economic and environmental terms) to dispose of manure and turn it into a resource. For this purpose, a thorough analysis of the starting farm situation and a wide knowledge of the territory with its resources and services is fundamental, from which to derive the most suitable and sustainable composting strategy. Naturally, a large diffusion of these manure management strategies should be assured by means of effective media in order to inform such a range of stakeholders on benefits of composting and of the use of its final product. A driving force, in this sense, could also come from the wide sharing of the other several positive benefits-often not known - of compost use in integrated but especially in organic farming (i.e., biostimulating effect on crop growth, suppressive properties against plant pathogens). Finally, farmers should be aware of the existence of a profitable market of the compost, due to its considerable agronomical value. This should encourage farmers in producing compost-from manure and other crop residues-to be sold to potential and emerging buyers (home gardeners, landscapers, vegetable farmers, nursery sector operators, operators of golf courses, ornamental crop growers). Such a condition could help farms, especially the small ones, to overcome those economic problems that often affect them.

Author Contributions: Conceptualization, G.C., A.M.P., R.S. and G.I.; methodology, A.P. and V.P.; software, M.P. and A.P.; validation, A.M.P. and M.P.; formal analysis, A.M.P. and M.P.; investigation, C.D., A.P. and G.I.; resources, A.M.P.; data curation, M.A.L., A.M.P. and A.P.; writing—original draft preparation, A.M.P.; writing-review and editing, A.M.P., M.P., A.P. and G.C.; visualization, V.P. and M.A.L.; supervision, G.C. and R.S.; project administration, G.C., R.S., L.MA. and C.D.; funding acquisition, G.C., R.S. and C.D. All authors have read and agreed to the published version of the manuscript

Funding: This research received no external funding

Acknowledgments: Research and transfer activities reported in this paper were financially supported by the following Projects: CarbOnFarm Project-LIFE +ENV/IT/000719; COMPOSTA Project-PSR Basilicata (measure 124); Progetto "Diffusione di nuove tecniche di compostaggio per la sostenibilità ambientale" Delibera del direttore ALSIA n. 181del 29/09/2016.

Conflicts of Interest: The authors declare no conflict of interest.

\section{References and Note}

1. Strijker, D. Marginal lands in Europe-Causes of decline. Basic Appl. Ecol. 2005, 6, 99-106. [CrossRef]

2. Thornton, P. Livestock production: Recent trends, future prospects. Philos. Trans. R. Soc. B Boil. Sci. 2010, 365, 2853-2867. [CrossRef] [PubMed]

3. EC. EU Agricultural Outlook for Markets and Income, 2019-2030; European Commission, DG Agriculture and Rural Development: Brussels, Belgium, 2019.

4. Eurostat. Agri-Environmental Indicator-Livestock Patterns. Available online: https: //ec.europa.eu/eurostat/statistics-explained/index.php/Agri-environmental_indicator_-_livestock_ patterns\#Livestock_density_at_EU_level_in_2016 (accessed on 3 December 2019).

5. ISTAT. VI Censimento Generale dell'Agricoltura; Istituto Nazionale di Statistica: Roma, Italy, 2010.

6. Foged, H.L.; Flotats, X.; Bonmati Blasi, A.; Palatsi, J.; Magri, A.; Schelde, K.M. Inventory of Manure Processing Activities in Europe; Technical Report No. I to the European Commission, Directorate-General Environment concerning "Manure Processing Activities in Europe"; Project reference: ENV.B.1/ETU/2010/0007; Agro Business Park: Tjele, Denmark, 2012; 138p.

7. European Commission. Collection and Analysis of Data for the Control of Emissions from the Spreading of Manure. 2014. Available online: https://ec.europa.eu/environment/air/pdf/Final\%20Report.pdf (accessed on 15 February 2020).

8. Yang, X.; Liu, E.; Zhu, X.; Wang, H.; Liu, H.; Liu, X.; Dong, W. Impact of Composting Methods on Nitrogen Retention and Losses during Dairy Manure Composting. Int. J. Environ. Res. Public Health 2019, 16, 3324. [CrossRef] [PubMed] 
9. Martinez, J.; Dabert, P.; Barrington, S.; Burton, C. Livestock waste treatment systems for environmental quality, food safety, and sustainability. Bioresour. Technol. 2009, 100, 5527-5536. [CrossRef] [PubMed]

10. EU Commission. Directive 91/676/EEC. Council Directive of 12 December 1991 concerning the protection of waters against pollution caused by nitrates from agricultural sources. Off. J. Eur. Community 1991, L375, 1-8.

11. Flotats, X.; Foged, H.L.; Bonmati Blasi, A.; Palatsi, J.; Magri, A.; Schelde, K.M. Manure Processing Technologies; Technical Report No. II to the European Commission, Directorate-General Environment concerning “Manure Processing Activities in Europe"; Project reference: ENV.B.1/ETU/2010/0007; Agro Business Park: Tjele, Denmark, 2011; 184p.

12. Brodie, H.L.; Carr, L.E.; Condon, P. A Comparison of Static Pile and Turned Windrow Methods for Poultry Litter Compost Production. Compos. Sci. Util. 2000, 8, 178-189. [CrossRef]

13. Breitenbeck, G.A.; Schellinger, D. Calculating the Reduction in Material Mass And Volume during Composting. Compos. Sci. Util. 2004, 12, 365-371. [CrossRef]

14. Rynk, R.; van de Kamp, M.; Willson, G.B.; Singley, M.E.; Richard, T.L.; Kolega, J.J.; Gouin, F.R.; Laliberty, L., Jr.; Kay, D.; Murphy, D.W.; et al. On-Farm Composting Handbook; Northeast Regional 610 Agricultural Engineering Service: Ithaca, NY, USA, 1992; p. 186.

15. Pergola, M.; Persiani, A.; Pastore, V.; Palese, A.M.; D’Adamo, C.; De Falco, E.; Celano, G. Sustainability Assessment of the Green Compost Production Chain from Agricultural Waste: A Case Study in Southern Italy. Agronomy 2020, 10, 230. [CrossRef]

16. Gitarskiy, M.; Yu, A. Izrael Institute of Global Climate and Ecology the Refinement To The 2006 Ipcc Guidelines For National Greenhouse Gas Inventories. Fundam. Appl. Clim. 2019, 2. [CrossRef]

17. Sánchez, A.; Artola, A.; Font, X.; Gea, T.; Barrena, R.; Gabriel, D.; Sanchez-Monedero, M.A.; Roig, A.; Cayuela, M.L.; Mondini, C. Greenhouse Gas from Organic Waste Composting: Emissions and Measurement. In CO2 Sequestration, Biofuels and Depollution; Lichtfouse, Z., Schwarzbauer, J., Robert, D., Eds.; Springer: Cham, Switzerland, 2015; Volume 5, pp. 33-70.

18. Misra, R.V.; Roy, R.N.; Hiraoka, H. On-farm Composting Methods; Food and Agriculture Organization of the United Nations (FAO): Rome, Italy, 2003; pp. 1-35.

19. ISO. International Standards Organisation, ISO 14044. Environmental Management-Life Cycle Assessment-Requirements and Guidelines. 2006. Available online: https://www.iso.org/standard/38498.html (accessed on 8 December 2019).

20. ISO. International Standards Organisation, ISO 14040. Environmental Management-Life Cycle Assessment_Requirements and Guidelines. 2006. Available online: https://www.iso.org/standard/37456.html (accessed on 8 December 2019).

21. Norhasmillah, A.H.; Puah, C.W.; Ibrahim, N.A.; Baharuddin, A.S.; Choo, Y.M. Lifecycle inventory of the commercial production of compost from oil palm biomass: A case study. Environ. Dev. Sustain. 2013, 15, 1663-1670. [CrossRef]

22. Saer, A.; Lansing, S.; Davitt, N.H.; Graves, R.E. Life cycle assessment of a food waste composting system: Environmental impact hotspots. J. Clean. Prod. 2013, 52, 234-244. [CrossRef]

23. Pergola, M.; Persiani, A.; Palese, A.M.; Di Meo, V.; Pastore, V.; D’Adamo, C.; Celano, G. Composting: The way for a sustainable agriculture. Appl. Soil Ecol. 2018, 123, 744-750. [CrossRef]

24. Guinée, J.B.; Gorrée, M.; Heijungs, R.; Huppes, G.; Kleijn, R.; de Koning, A.; van Oers, L.; Wegener Sleeswijk, A.; Suh, S.; Udo de Haes, H.A.; et al. Handbook on life cycle assessment. Operational guide to the ISO standards. I: LCA in perspective. IIa: Guide. IIb: Operational annex. III: Scientific background; Kluwer Academic Publishers: Dordrecht, The Netherlands, 2002; 692p, ISBN 1-4020-0228-9.

25. Monarca, D.; Biondi, P.; Panaro, V.N.; Colantoni, A.; Bartoli, S.; Cecchini, M. Analisi delle richieste di energia per la coltivazione delle colture ortive. In Proceeding of IX Convegno Naz. Dell'Associazione Italiana di Ingegneria Agraria Memoria, Ischia Porto (Naples), Italy, 12-16/09/2009; Doppiavoce Napoli: Naples, Italy, 2009; pp. 10-12.

26. Page, G. An Environmentally E Based Systems Approach to Sustainability Analysis of Organic Fruit Production Systems in New Zealand. Ph.D. Thesis, Massey University, Palmerston North, New Zealand, 2009.

27. Lovell, P.H.; Pimental, D.; Pimental, M. Food, Energy and Society. J. Appl. Ecol. 1982, 19, 308. [CrossRef]

28. Volpi, R. Bilanci Energetici in Agricoltura; Laruffa Editore: Reggio Calabria, Italy, 1992.

29. Ruggieri, L.; Cadena, E.; Martínez-Blanco, J.; Gasol, C.M.; Rieradevall, J.; Gabarrell, X.; Gea, T.; Sort, X.; Sánchez, A. Recovery of organic wastes in the Spanish wine industry. Technical, economic and environmental analyses of the composting process. J. Clean. Prod. 2009, 17, 830-838. [CrossRef] 
30. Mu, D.; Horowitz, N.; Casey, M.; Jones, K. Environmental and economic analysis of an in-vessel food waste composting system at Kean University in the U.S. Waste Manag. 2017, 59, 476-486. [CrossRef] [PubMed]

31. Pergola, M.; D’Amico, M.; Celano, G.; Palese, A.M.; Scuderi, A.; Di Vita, G.; Pappalardo, G.; Inglese, P. Sustainability evaluation of Sicily's lemon and orange production: An energy, economic and environmental analysis. J. Environ. Manag. 2013, 128, 674-682. [CrossRef] [PubMed]

32. Pergola, M.; Persiani, A.; Pastore, V.; Palese, A.M.; Arous, A.; Celano, G. A comprehensive Life Cycle Assessment (LCA) of three apricot orchard systems located in Metapontino area (Southern Italy). J. Clean. Prod. 2017, 142, 4059-4071. [CrossRef]

33. Scotti, R.; Pane, C.; Spaccini, R.; Palese, A.M.; Piccolo, A.; Celano, G.; Zaccardelli, M. On-farm compost: A useful tool to improve soil quality under intensive farming systems. Appl. Soil Ecol. 2016, 107, 13-23. [CrossRef]

34. Pane, C.; Celano, G.; Piccolo, A.; Villecco, D.; Spaccini, R.; Palese, A.M.; Zaccardelli, M. Effects of on-farm composted tomato residues on soil biological activity and yields in a tomato cropping system. Chem. Boil. Technol. Agric. 2015, 2, 169. [CrossRef]

35. Decreto Legislativo 29 Aprile 2010, n. 75. Riordino e Revisione della Disciplina in Materia di Fertilizzanti, a Norma Dell'articolo 13 Della Legge 7 Luglio 2009.

(C) 2020 by the authors. Licensee MDPI, Basel, Switzerland. This article is an open access article distributed under the terms and conditions of the Creative Commons Attribution (CC BY) license (http://creativecommons.org/licenses/by/4.0/). 